\title{
PERANCANGAN DAN PEMBANGUNAN SISTEM INFORMASI INVENTARISASI BARANG PT. TUNAS JAYA SANUR
}

\author{
(Designing and Building of Information System for Mail Archiving at PT. Tunas Jaya \\ Sanur)
}

\author{
Umbara Diki Pratama $^{[1]}$, Fitri Bimantoro ${ }^{[1]}$, Muhammad Edy Kurniawan Basri ${ }^{[2]}$ \\ ${ }^{[1]}$ Dept Informatics Engineering, University of Mataram \\ J1. Majapahit 62, Mataram, Lombok NTB, INDONESIA \\ ${ }^{[2]}$ PT. Tunas Jaya Sanur Mataram \\ Jl, Adi Sucipto, No. 77, Kel. Dayan Peken, Kec. Ampenan, Mataram, Lombok NTB, Indonesia \\ Email:yanthieka66@gmail.com,bimo@unram.ac.id, edykurniawanbasri@pttjs.id
}

\begin{abstract}
Abstrak
Hingga saat ini inventarisasi barang masih sering dilakukan secara manual atau konvensional, yang mana sering menyebabkan terjadinya kesalahan dalam penyimpanan dan pencarian data barang. Kesulitan tersebut dapat diatasi dengan membuat suatu sistem informasi, yaitu dengan menggunakan bahasa pemrograman PHP dan database MySQL untuk mengelola barang. Sistem informasi ini bertujuan untuk mengubah cara pengelolaan dan inventarisasi barang yang semula secara hard copy menjadi soft copy, sehingga dapat mempermudah pengguna dalam melakukan inventarisasi barang. Metode yang digunakan adalah waterfall dengan beberapa tahapan yang runtut dari analisis kebutuhan, desain sistem, coding dan testing, penerapan program, serta pemeliharaan. Pengujian menggunakan user acceptance testing yang di dalamnya terdapat pengujian black box dan kuesioner. Berdasarkan pengujian yang telah dilakukan, maka didapatkan hasil bahwa responden yang merupakan karyawan di PT. Tunas Jaya Sanur setuju dengan sistem informasi inventarisasi barang yang telah dibuat.
\end{abstract}

Keywords: Sistem Informasi, PHP, MySQL, Metode Waterfall, User Acceptance Testing.

\section{Pendahuluan}

\subsection{Latar Belakang}

Di era globalisasi ini perkembangan teknologi dari waktu ke waktu begitu pesat sehingga membuat pekerjaan manusia dipermudah dengan adanya teknologi saat ini, yang pada umumnya akan diselesaikan dengan cepat. Teknologi merupakan salah satu alat bantu yang sering digunakan pada aktivitas manusia, yang mana perannya begitu penting seperti halnya dalam mendapatkan suatu informasi dengan cepat ataupun mendata suatu informasi [1]. Dari peran ini, teknologi mampu mengolah suatu data dengan efisien dan terstruktur sehingga dapat bermanfaat bagi pengguna teknologi. Pengolahan data begitu perlu dilakukan pada setiap instansi ataupun organisasi yang mana data yang bernilai informasi mampu meningkatkan produktivitas pekerjaan, waktu dan biaya.

PT. Tunas Jaya Sanur adalah perusahaan kontraktor terdiversifikasi yang didirikan di Bali, Indonesia pada tahun 1978. Sejak itu, PT Tunas Jaya Sanur telah berkembang menjadi salah satu perusahaan konstruksi dan fabrikasi terbesar di Bali dengan pengalaman luas baik di segmen pasar Indonesia maupun Internasional bahkan berhasil memperluas pasarnya dengan mendirikan kantor cabang di Kota Mataram, Nusa Tenggara Barat. PT. Tunas Jaya Sanur Cabang Mataram memiliki anggaran dasar yang dibutuhkan para karyawan untuk menjalankan perusahaan berupa ATK dan alat-alat kebutuhan proyek yang disimpan di gudang.

Inventarisasi barang secara manual dalam jangka waktu panjang akan menyebabkan terjadinya penumpukan data arsip yang ada, baik itu barang masuk dan barang keluar. Sehingga dapat menyulitkan karyawan dalam mencari suatu data barang yang telah lama. Selain itu, inventarisasi barang juga akan memakan ruang jika terus dilakukan secara manual.

Sistem informasi merupakan suatu sistem yang menyediakan informasi untuk memanajemen dalam mengambil keputusan dan juga untuk menjalankan operasional perusahaan, yang mana sistem tersebut merupakan kombinasi dari manusia, sistem informasi, dan prosedur-prosedur yang terorganisasi [2]. Dengan adanya sistem 
informasi dapat mempermudah dalam melakukan pendataan atau pengelolaan dari sistem yang akan dibuat nantinya.

Maka dari itu, pada pengabdian masyarakat ini perlu dibuat sebuah sistem informasi inventarisasi barang untuk dapat mempermudah dalam melakukan pengarsipan, pendataan serta pengelolaan barang-barang atau alatalat yang ada serta membuat proses inventarisasi lebih mudah serta lebih efektif, karena operator tidak perlu lagi melakukan inventarisasi secara manual.

\subsection{Rumusan Masalah}

Berdasarkan latar belakang yang telah dipaparkan, maka dapat dirumuskan pokok permasalahan yaitu bagaimana cara merancang sistem inventarisasi barang di gudang berbasis web yang dapat digunakan untuk mempermudah pengelolaan barang di gudang pada PT. Tunas Jaya Sanur.

\subsection{Batasan Masalah}

Berdasarkan rumusan masalah yang telah dipaparkan, dapat diambil rumusan masalah adalah sebagai berikut:

a. Sistem informasi stok barang pada PT. Tunas Jaya Sanur merupakan sebuah sistem informasi berbasis web yang memiliki beberapa fitur untuk melihat maupun mengelola data barang di gudang untuk barang masuk dan barang keluar, menambahkan data barang masuk maupun barang keluar, dan mengelola pelaporan.

b. Sistem yang dibangun merupakan sebuah sistem informasi yang dapat digunakan oleh karyawan PT. Tunas Jaya Sanur.

c. Sistem informasi yang akan dibuat berbasis web dengan menggunakan Bahasa pemrograman PHP dan MySQL.

\subsection{Tujuan}

Tujuan dari pembuatan sistem informasi inventarisasi barang pada PT. Tunas Jaya Sanur ini adalah:

a. Merancang dan membuat sebuah sistem informasi stok barang berbasis web sebagai sarana pengelolaan barang di gudang pada PT. Tunas Jaya Sanur.

b. Mempermudah pengarsipan, pengelolaan, dan penyimpanan stok barang pada PT. Tunas Jaya Sanur.

\subsection{Manfaat}

Manfaat dari pembuatan sistem inventarisasi barang pada PT. Tunas Jaya Sanur ini adalah sebagai berikut:

a. Bagi Operator

1. Inventarisasi barang dapat lebih terstruktur dan juga lebih hemat kertas jika dibandingkan dengan inventarisasi barang secara manual.

2. Dengan adanya sistem informasi inventarisasi barang pada PT. Tunas Jaya Sanur ini, operator akan lebih mudah untuk mengelola pegarsipan barang.

3. Dapat memudahkan operator untuk melakukan pencarian barang-barang yang ada.

b. Bagi Mahasiswa

1. Pada proses pembuatan sistem informasi ini, mahasiswa dapat menerapkan dan dapat menambah pemahaman dalam pembuatan web menggunakan PHP dan MySQL.

2. Menambah pengalaman mahasiswa dalam bekerja pada suatu instansi.

\section{TinJauan Pustaka}

\subsection{Sistem Informasi}

Sistem informasi adalah kumpulan dari sub sistem apa pun baik fisik ataupun non-fisik yang saling berhubungan satu sama lain dan bekerja sama secara harmonis untuk mencapai satu tujuan yaitu mengolah data menjadi informasi yang memiliki arti dan berguna [3]. Selain itu sistem informasi adalah suatu sistem di dalam suatu organisasi yang mempertemukan kebutuhan pengolahan transaksi harian, mendukung operasi, bersifat manajerial dan kegiatan strategi dari suatu organisasi dan menyediakan pihak luar tertentu dengan laporan-laporan yang diperlukan [4]. Pengertian lain juga mengatakan bahwa sistem informasi adalah suatu sistem di dalam organisasi yang mempertemukan kebutuhan pengelolaan transaksi harian yang mendukung fungsi organisasi yang manajerial dalam kegiatan strategi dari suatu organisasi untuk dapat menyediakan pihak luar tertentu dengan laporan-laporan yang di perlukan [5]. 


\subsection{Basis Data}

Basis data terdiri dari 2 kata, yaitu basis dan data. Basis kurang lebih diartikan sebagai markas atau gudang, tempat bersarang/berkumpul. Sedangkan data adalah representasi fakta dunia nyata yang mewakili suatu objek seperti manusia (pegawai, siswa, pembeli, pelanggan), barang, hewan, peristiwa, konsep, keadaan, dan sebagainya, yang direkam dalam bentuk angka, huruf, simbol, teks, gambar, bunyi/suara, atau kombinasinya [6].

\subsection{UML}

Unified Modelling Language merupakan alat perancangan sistem yang berorientasi pada objek. UML diagram memiliki tujuan utama untuk membantu tim pengembangan proyek berkomunikasi, mengeksplorasi potensi desain, dan memvalidasi desain arsitektur perangkat lunak atau pembuat program [7].

\subsection{ERD}

ERD (Entity Relationship Diagram) merupakan sebuah diagram yang digunakan untuk merancang hubungan antar tabel-tabel dalam basis data [6]. ERD (Entity Relation Diagram) berguna untuk menggambarkan gambaran dari dunia nyata yang akan diterapkan pada suatu database sebuah sistem. ERD melihat objek nyata dapat sebagai sebuah entitas - entitas yang memiliki relasi antara entitas yang satu ataupun yang lain. Dengan ERD sendiri dapat membantu mengurangi kesalahan - kesalahan dalam melakukan perancangan database dari gambaran dunia nyata dan struktur database seperti redundansi data, hubungan - hubungan antara entitas, dan lain sebagainya.

\subsection{PHP}

PHP digunakan sebagai bahasa script server-side dalam pengembangan web yang disisipkan pada dokumen HTML. Penggunaan PHP memungkinkan web dapat dibuat dinamis sehingga maintenance situs web tersebut menjadi lebih mudah dan efisien [8].

\subsection{MySQL}

SQL (Structured Query Language) adalah sebuah bahasa yang dipergunakan untuk mengakses data dalam basis data relasional. SQL juga dapat diartikan sebagai antar muka standar untuk sistem manajemen basis data relasional, termasuk sistem yang beroperasi pada komputer pribadi. SQL memungkinkan seorang pengguna untuk mengakses informasi tanpa mengetahui di mana lokasinya atau bagaimana informasi tersebut disusun.

MySQL adalah salah satu aplikasi DBMS yang sudah sangat banyak digunakan oleh para programmer aplikasi web. MySQL merupakan DBMS open source (kode programnya dapat di-download gratis) dan freeware (gratis dipakai), walau gratis MySQL tidak bisa dikatakan DBMS kurang baik karena gratis, hal ini terbukti dengan adanya sebuah operator telepon selular yang menggunakan DBMS ini dan memiliki sistem yang andal dengan optimasi. Sampai saat ini MySQL masih menjadi DBMS open source paling banyak digunakan di dunia. MySQL terkenal dengan kecepatan dalam pengaksesan datanya. MySQL saat ini dimiliki oleh perusahaan Oracle [9].

\subsection{Bootstrap}

Bootstrap merupakan framework untuk membangun desain web secara responsif. Artinya, tampilan web yang dibuat oleh bootstrap akan menyesuaikan ukuran layer dan browser yang kita gunakan baik di desktop, tablet ataupun mobile device. Dengan bootstrap kita juga bisa membangun web dinamis ataupun statis [10].

\subsection{XAMPP}

XAMPP adalah perangkat lunak bebas yang mendukung banyak sistem informasi, merupakan kompilasi dari beberapa program. Fungsinya adalah sebagai server yang berdiri sendiri (localhost), yang terdiri atas program Apache, HTTP Server, MySQL database, dan penerjemah bahasa yang ditulis dengan bahasa pemrograman PHP dan Perl [9].

\section{Metode Pengabdian Masyarakat}

\subsection{Metode Pelaksanaan Kegiatan}

Pelaksanaan kegiatan dilakukan dengan identifikasi masalah pada instansi terkait, yaitu PT. Tunas Jaya Sanur yang akan digunakan untuk membangun sistem informasi sertifikasi badan usaha dan tenaga kerja. Dilakukan juga studi literatur untuk mengetahui bagaimana sistem informasi ini bisa berjalan dengan semestinya, dimana dalam kasus ini penerapan bahasa pemrograman menggunakan PHP untuk membuat sistem informasi berbasis website dan komponen pendukung dalam menyelesaikan sistem. Pada tahap ini diperlukan juga komunikasi yang bertujuan untuk memahami perangkat lunak yang diharapkan oleh pengguna dan batasan perangkat lunak tersebut. Informasi ini menggunakan metode wawancara, diskusi dan survei langsung. Kemudian informasi dianalisis untuk mendapatkan data yang dibutuhkan oleh instansi terkait yaitu PT. Tunas Jaya Sanur.

\subsection{Waktu Kegiatan}

Pelaksanaan kegiatan berjalan selama 2 bulan termasuk waktu persiapan. Persiapan-persiapan yang perlu dilakukan sebelum pengabdian di antaranya: 
1. Melakukan identifikasi kasus terkait kebutuhan sistem yang akan didata menggunakan cara survei dan bertanya langsung pada pegawai PT. Tunas Jaya Sanur.

2. Menetapkan hari, tanggal kegiatan, lokasi dan alat-alat yang perlu dipersiapkan untuk melaksanakan kegiatan.

3. Merancang sistem informasi inventarisasi barang.

4. Menerapkan bahasa pemrograman PHP untuk membuat sistem informasi inventarisasi berbasis website dan komponen pendukung untuk merampungkan sistem.

5. Mempersiapkan bahan demonstrasi sistem yang sudah dibuat $\&$ dibuat.

6. Melakukan uji coba data uji dalam sistem yang sudah jadi sekaligus presentasi pada pegawai PT. Tunas Jaya Sanur.

7. Mempersiapkan ulasan dan penilaian presentasi pada bentuk kuesioner yang akan dibagikan pada pegawai menjadi pengguna pelaksanaan \& responden

\subsection{Peserta Kegiatan}

Peserta kegiatan pembinaan sistem informasi inventarisasi barang PT. Tunas Jaya Sanur merupakan kepala cabang dan pegawai dari Departemen $S D M \&$ Procurement dan Departemen Operasional yang bertugas sebagai operator dan pengawas sistem informasi inventarisasi barang.

\subsection{Analisis Kebutuhan}

Pada Praktik Kerja Lapangan di PT. Tunas Jaya Sanur ini dilakukan analisis kebutuhan yang diperlukan dalam pembuatan sistem informasi inventarisasi barang dengan tahapan sebagai berikut:

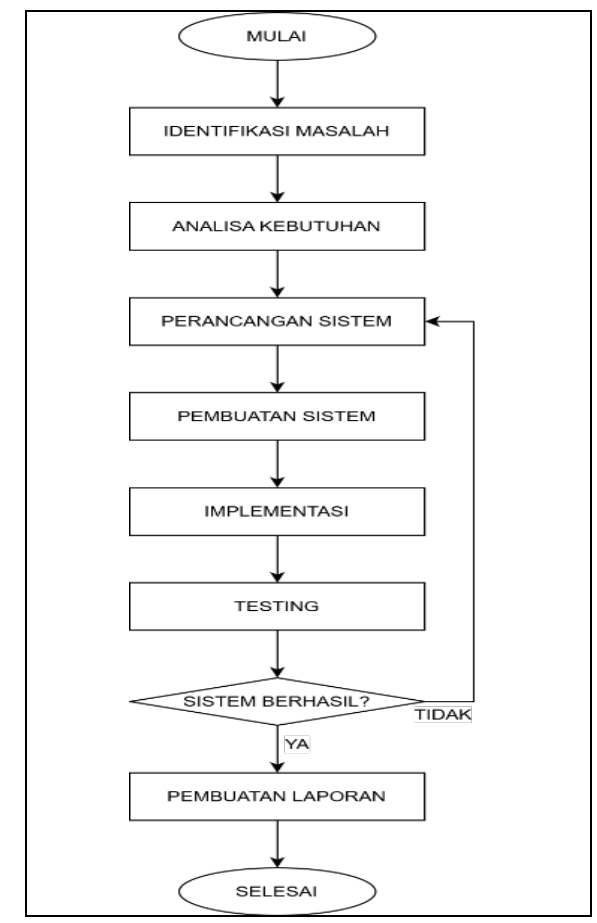

Gambar 1. Flowchart pembuatan sistem informasi

Berdasarkan flowchart pada Gambar 1, proses pembuatan sistem informasi inventarisasi barang dimulai dengan melakukan identifikasi masalah yang ada pada PT. Tunas Jaya Sanur dalam hal inventarisasi barang. Setelah melakukan identifikasi masalah, dilanjutkan dengan analisis kebutuhan yang diperlukan dalam pembuatan sistem informasi inventarisasi barang, baik dengan menganalisis metode sebelumnya dengan metode yang akan dibuat. Selanjutnya dilakukan perancangan sistem, seperti menentukan metode yang digunakan, alur dari program, dan sebagainya. Setelah perancangan dilakukan, maka akan dilakukan pembuatan sistem informasi inventarisasi barang. Setelah program selesai dibuat, kemudian dilakukan implementasi dan testing dari sistem yang dibuat. Jika program berhasil, maka akan dilanjutkan dengan pembuatan laporan, namun sebaliknya jika program belum berhasil, maka akan dilakukan perbaikan dimulai dari perancangan sistem, dan akan terus diulang sampai program berhasil dan selesai.

\subsection{Metode Perancangan Sistem}


Metode yang digunakan dalam perancangan sistem informasi inventarisasi barang PT. Tunas Jaya Sanur ini adalah metode waterfall. Metode waterfall adalah suatu proses pengembangan perangkat lunak berurutan, di mana kemajuan dipandang sebagai terus mengalir ke bawah (seperti air terjun) melewati fase-fase perencanaan, pemodelan, implementasi (konstruksi), dan pengujian. Dalam pengembangannya metode waterfall memiliki beberapa tahapan yang runtut: requirement (analisis kebutuhan), desain sistem (sistem design), coding dan testing, penerapan program, serta pemeliharaan [11].

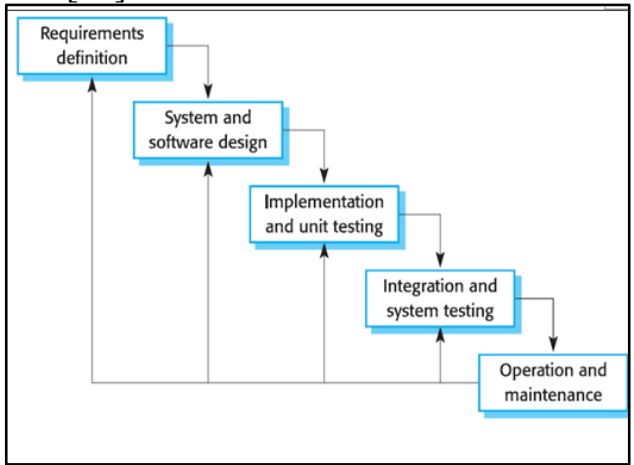

Gambar 2. Metode Waterfall

\subsection{Desain Sistem}

Sistem informasi inventarisasi barang PT. Tunas Jaya Sanur memiliki diagram seperti use case diagram, class diagram, sequence diagram, activity diagram, dan ERD sebagai berikut:

\subsubsection{Use Case Diagram}

Gambar 3 merupakan use case diagram dari sistem informasi pengarsipan barang pada PT. Tunas Jaya Sanur. Pada use case diagram tersebut, sistem yang dibuat hanya memiliki satu orang aktor, yaitu admin. Pada sistem informasi ini, admin atau yang mengelola sistem dapat melakukan proses-proses sebagai berikut:

a. Melihat dashboard, profil, daftar barang masuk, daftar barang keluar, buku agenda barang masuk, dan buku agenda barang keluar.

b. Menambah barang masuk dan barang keluar.

c. Mengedit profil, barang masuk, dan barang keluar.

d. Menghapus barang masuk dan barang keluar.

e. Mencetak buku agenda barang masuk dan buku agenda barang keluar.

f. Mengganti password.

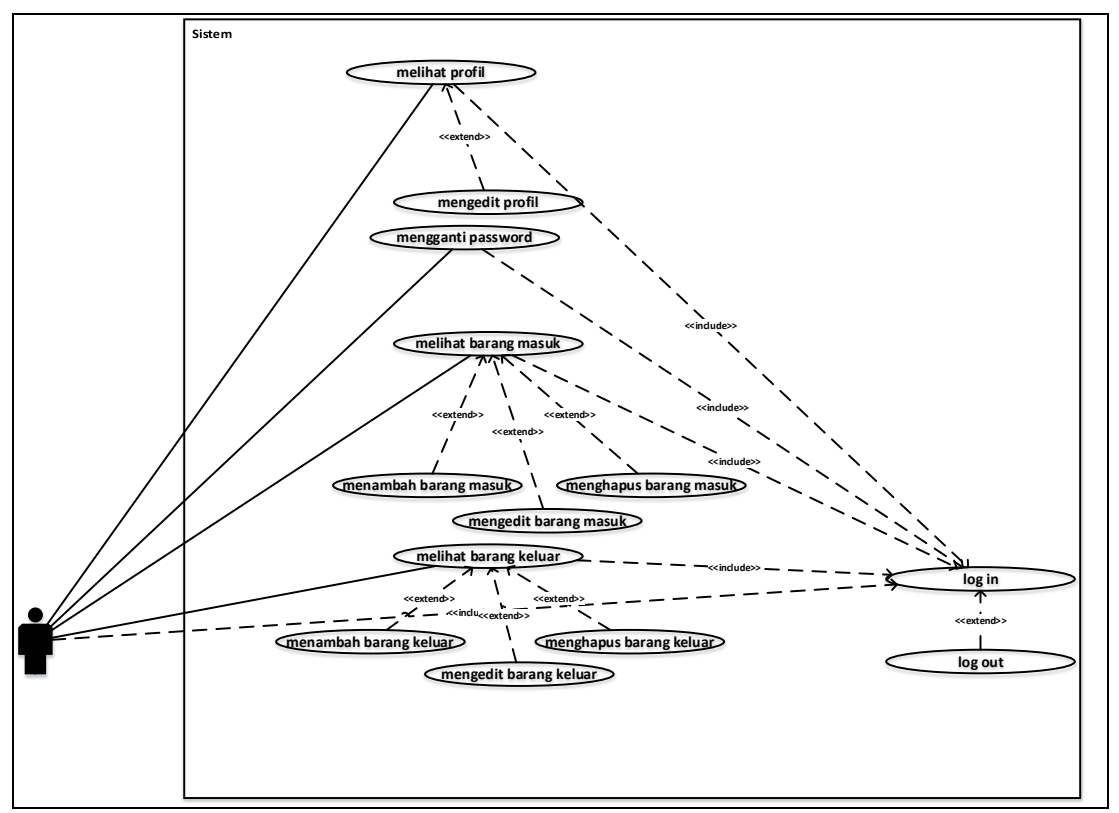

Gambar 3. Use case diagram sistem informasi pengarsipan barang 


\subsubsection{Class Diagram}

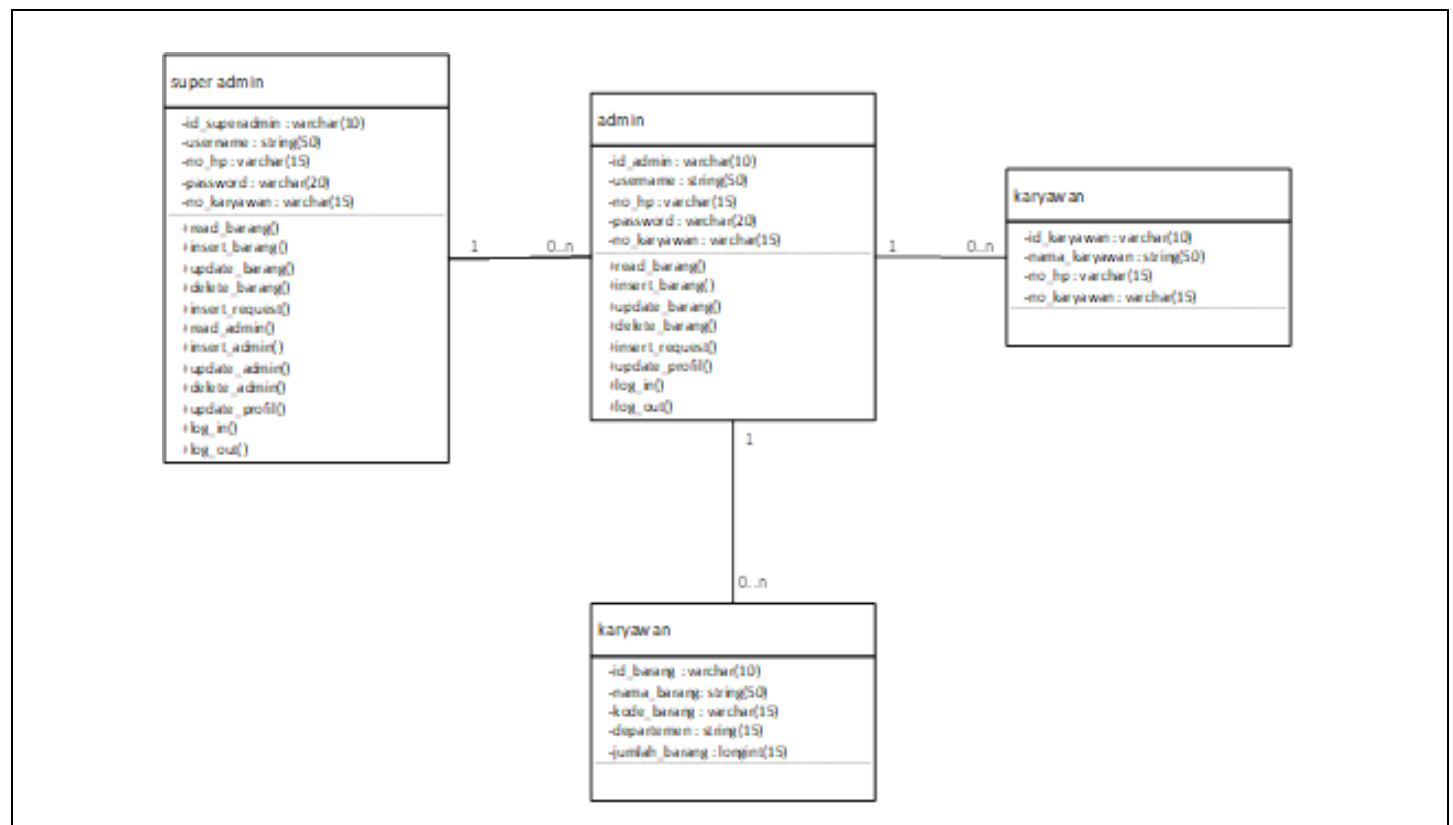

Gambar 4. Class diagram tambah barang

Gambar 4 merupakan class diagram dari sistem informasi pengarsipan barang pada PT Tunas Jaya Sanur, dimana terdapat empat buah kelas yang saling berinteraksi.

\subsubsection{Sequence Diagram}

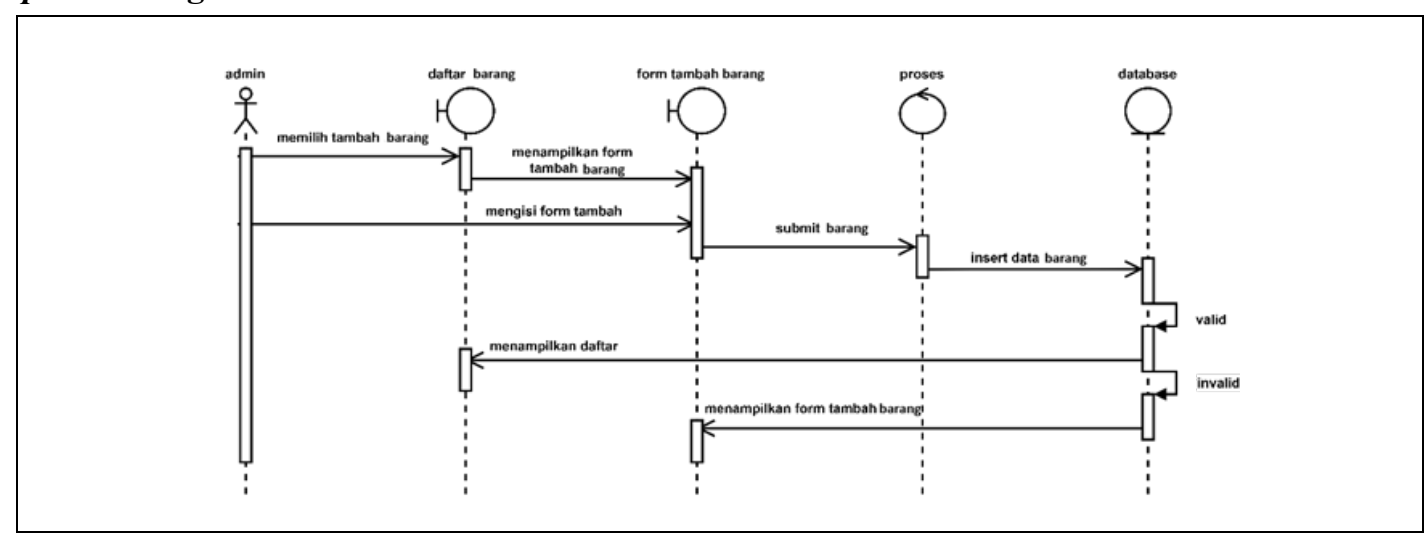

Gambar 5. Sequence diagram tambah barang

Gambar 5 merupakan sequence diagram dari melakukan tambah barang. Berdasarkan sequence diagram tersebut, saat melakukan tambah barang admin akan memilih tambah barang yang terdapat pada halaman daftar barang, setelah itu form tambah barang akan ditampilkan dan admin akan mengisi form tersebut, lalu admin akan melakukan submit, setelah itu data barang akan diproses dan dilakukan insert data barang pada database, jika data yang ditambahkan valid maka selanjutnya akan ditampilkan halaman daftar barang, jika tidak maka akan tetap berada pada halaman form tambah barang.

\subsubsection{Activity Diagram}

Gambar 6 merupakan activity diagram dari proses menambah barang. Berdasarkan activity diagram tersebut, user akan memilih menu tambah barang, kemudian sistem kana menampilkan form tambah barang, selanjutnya user akan mengisi form dan melakukan submit, setelah itu dilakukan pengecekan, jika data sesuai atau lengkap tanpa 
kesalahan, maka sistem akan menampilkan halaman daftar barang, sebaliknya jika data tidak sesuai, maka akan tetap berada di halaman form.

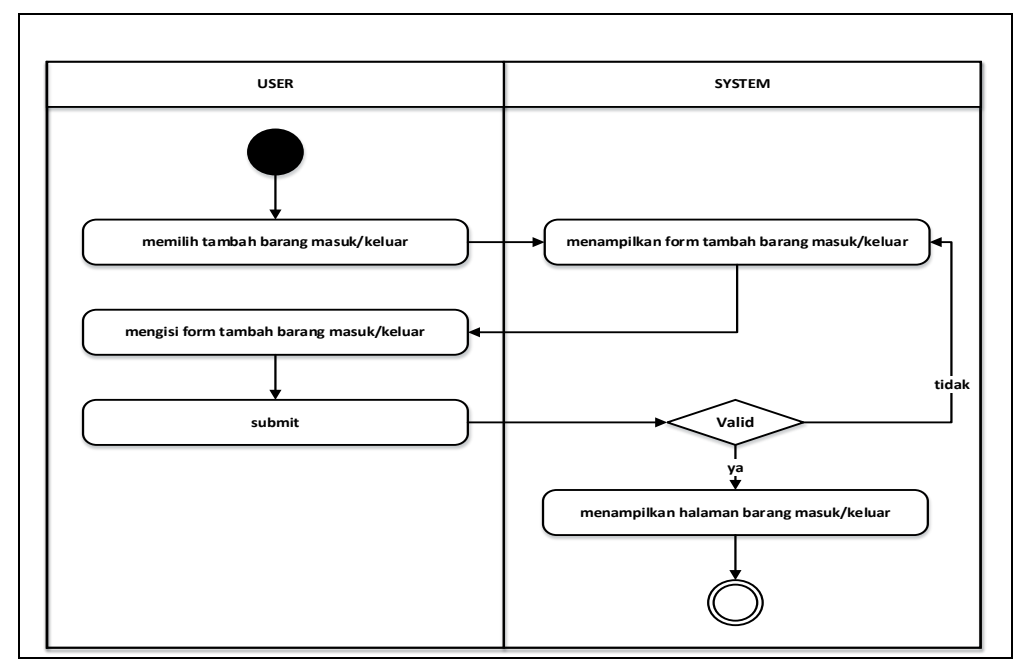

Gambar 6. Activity diagram tambah barang

\subsubsection{Entity Relationship Diagram}

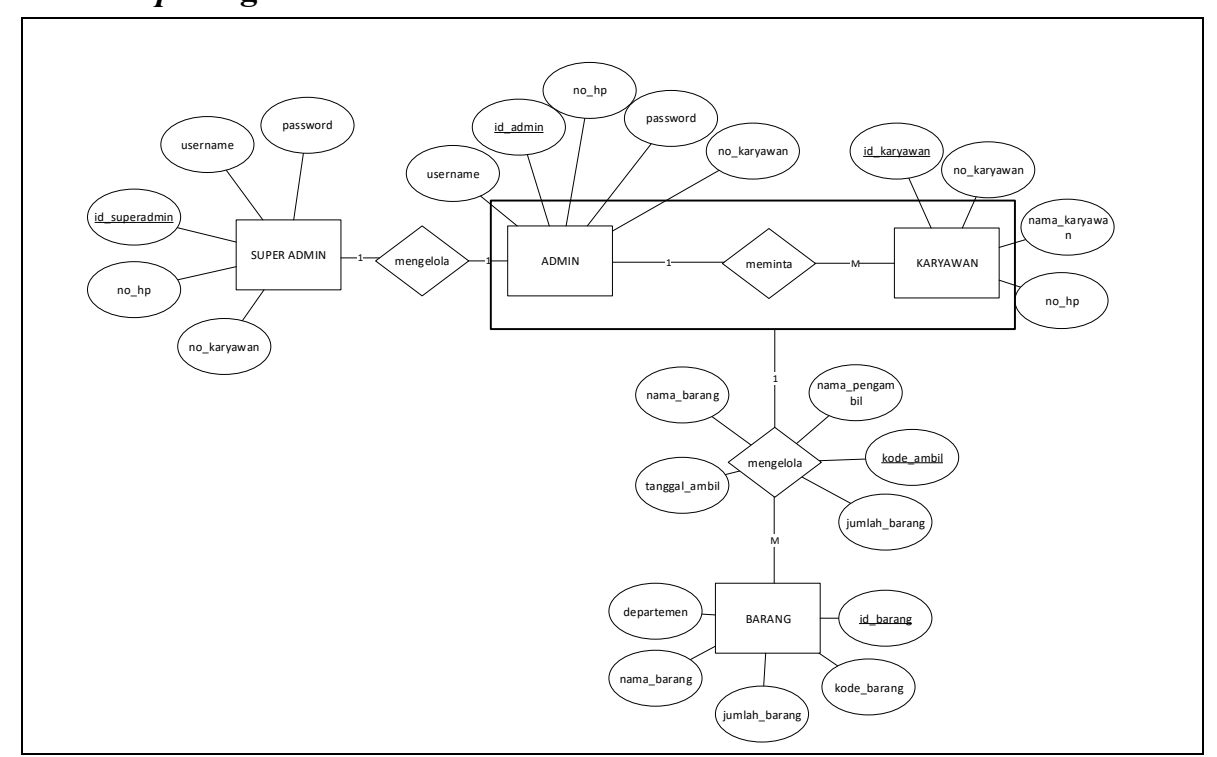

Gambar 7. ERD sistem informasi pengarsipan barang

\subsubsection{Implementasi Sistem}

a. $\quad \log I n$

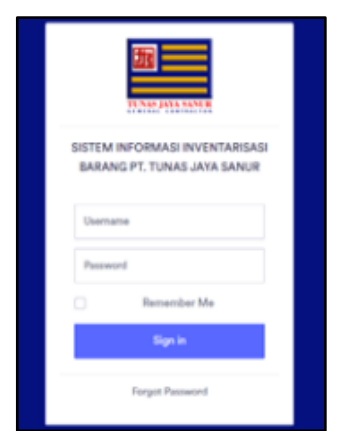

Gambar 8. $\log$ In 
Gambar 8 merupakan implementasi dari halaman log in dalam sistem informasi inventarisasi barang pada PT. Tunas Jaya Sanur. Halaman ini adalah halaman yang pertama kali ditampilkan saat admin membuka sistem informasi inventarisasi barang.

b. Daftar Barang Masuk

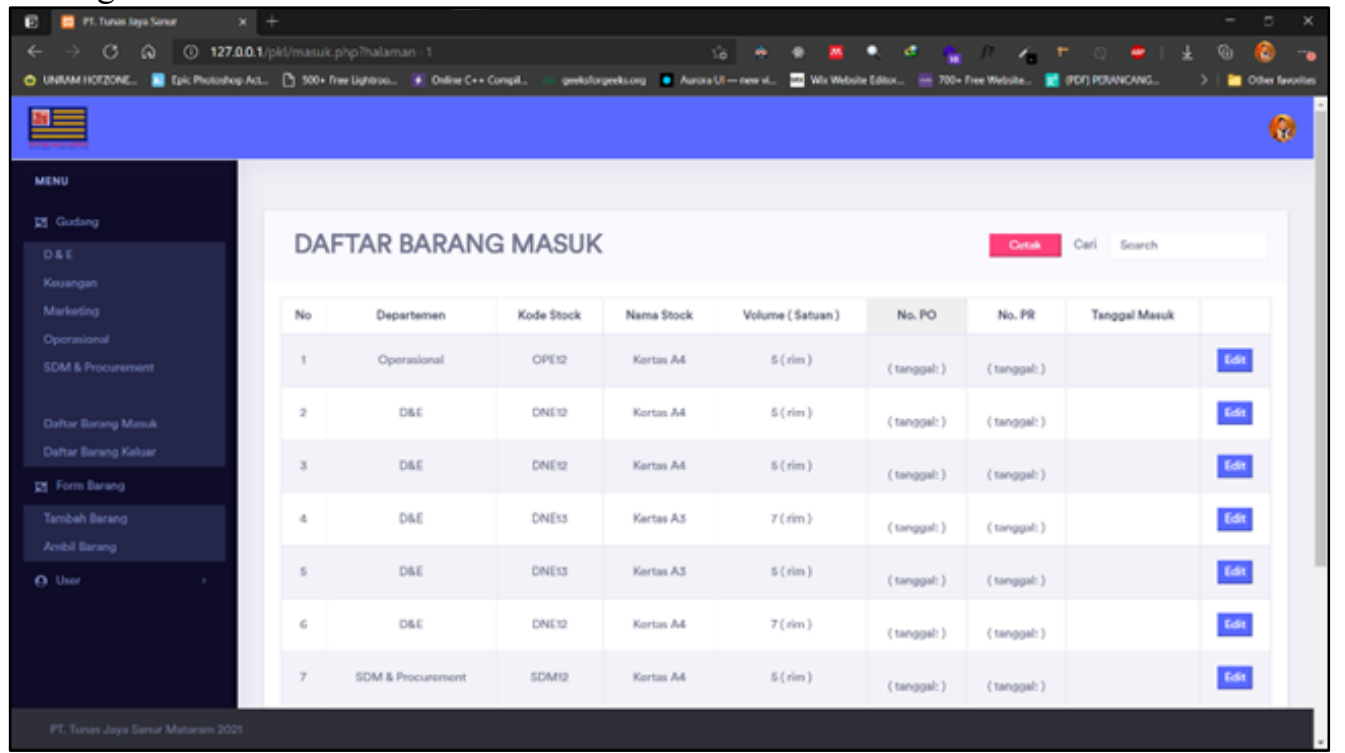

Gambar 9. Daftar barang masuk

Gambar 9 merupakan implementasi dari halaman daftar barang masuk dalam sistem informasi inventarisasi barang pada PT. Tunas Jaya Sanur. Halaman ini adalah halaman yang digunakan admin untuk melihat daftar data barang masuk, serta terdapat beberapa tombol yang digunakan untuk melakukan tambah barang, edit barang, dan hapus barang.

c. Tambah Barang Masuk

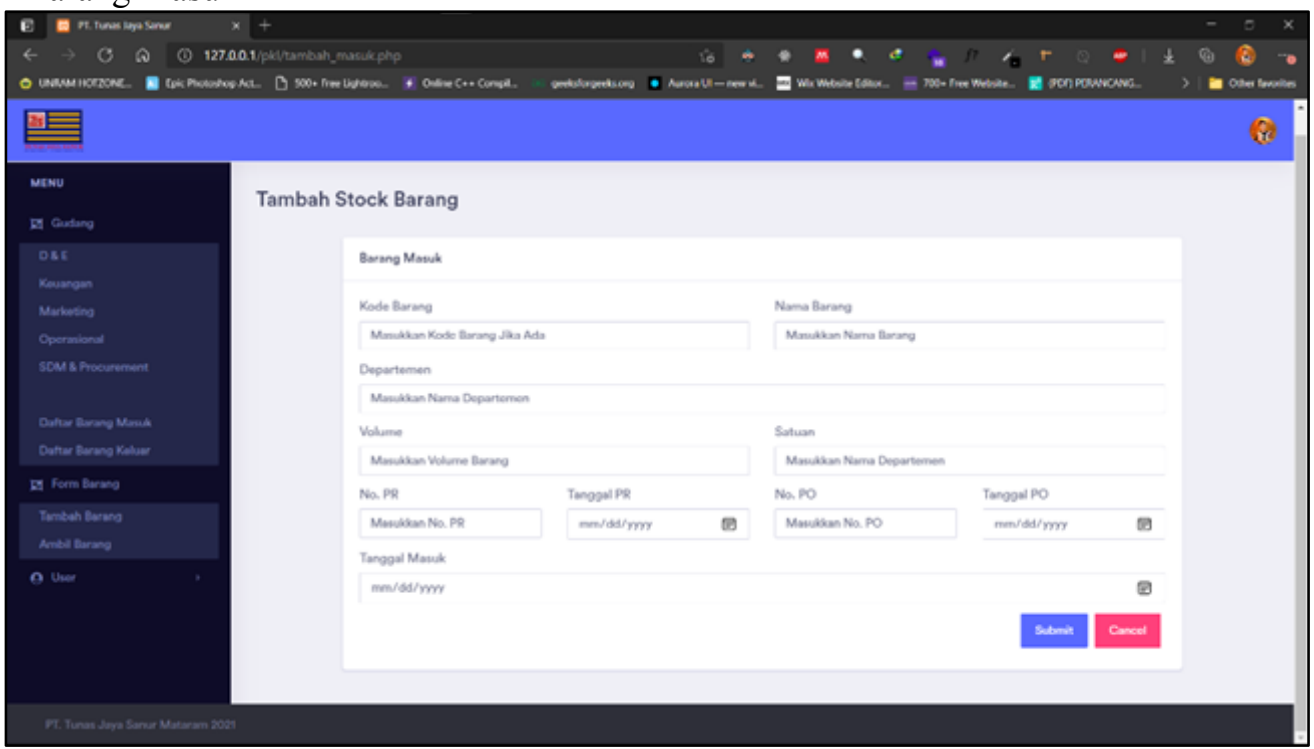

Gambar 10. Tambah barang masuk

Gambar 10 merupakan implementasi dari halaman tambah barang masuk dalam sistem informasi inventarisasi barang pada PT. Tunas Jaya Sanur. Halaman ini akan ditampilkan ketika admin memilih tombol tambah barang pada daftar barang masuk. Pada halaman ini admin dapat menambahkan data barang masuk, seperti nomor barang, perihal, tanggal barang, asal barang, dan file. 
d. Edit Barang Masuk

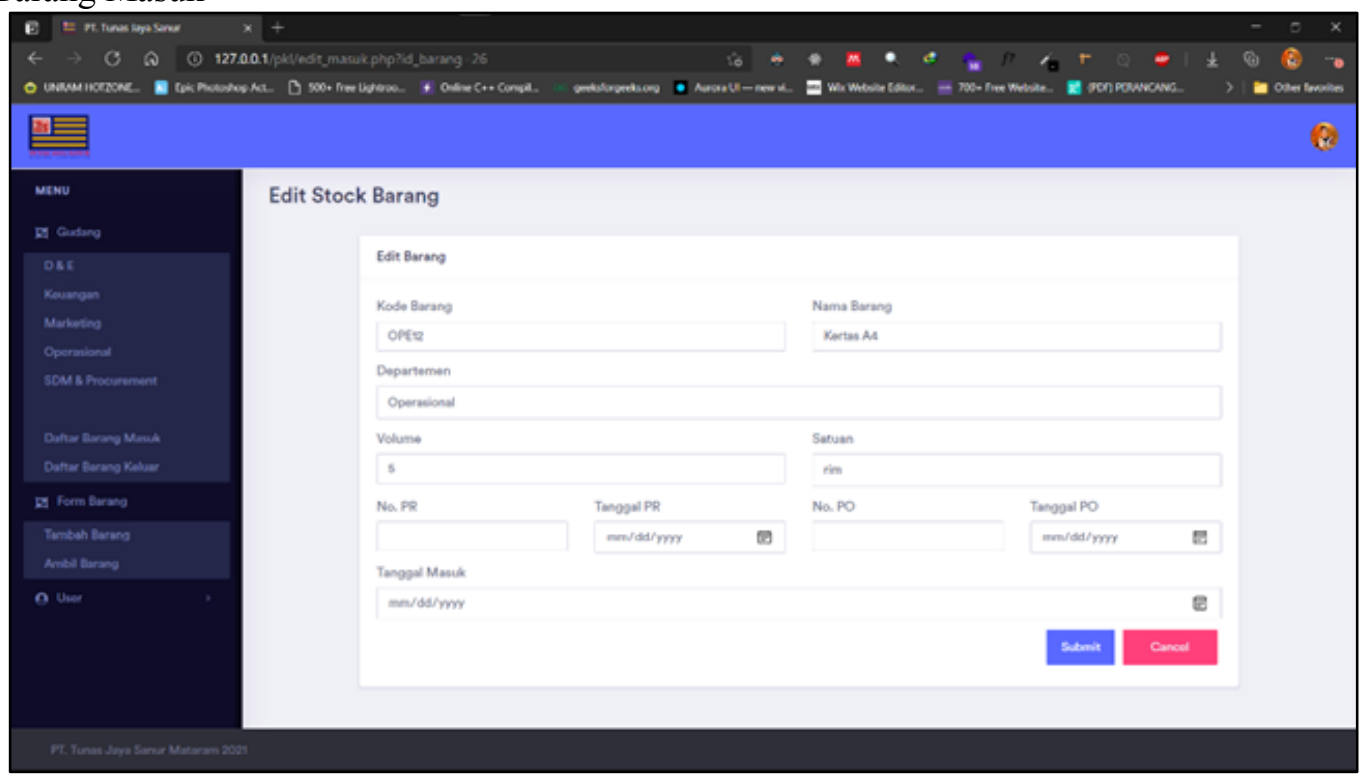

Gambar 11. Edit barang masuk

Gambar 11 merupakan implementasi dari halaman edit barang masuk dalam sistem informasi inventarisasi barang pada PT. Tunas Jaya Sanur. Halaman ini akan ditampilkan ketika admin memilih tombol edit barang pada daftar barang masuk. Pada halaman ini admin dapat mengubah data barang masuk, seperti nomor barang, perihal, tanggal barang, asal barang, dan file.

\section{HASil DaN PEMbahasan}

Pengujian sistem informasi pengarsipan barang pada PT. Tunas Jaya Sanur menggunakan metode user acceptance testing. Metode user acceptance testing menggunakan black box testing dan kuesioner dalam pengujiannya. Berikut hasil implementasi sistem dan pengujian yang telah dilakukan:

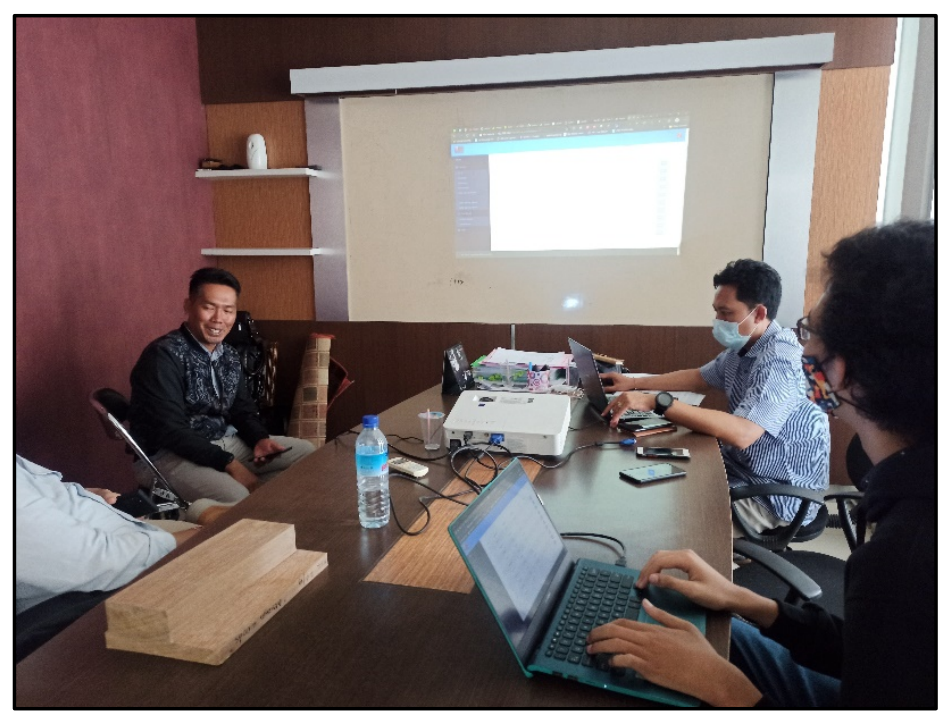

Gambar 12. Presentasi pengujian sistem

Gambar 12 merupakan dokumentasi pada saat uji coba sistem bersama pegawai dan kepala cabang. Proses presentasi berjalan lancar dan tidak ada kendala berarti karena para pegawai sudah familier dengan cara kerja sistem, sehingga pegawai cepat beradaptasi untuk menggunakan sistem. 


\subsection{Black Box Testing}

Metode pengujian black box merupakan metode pengujian yang menguji fungsi-fungsi di dalam sistem untuk menentukan apakah fungsi-fungsi tersebut sudah berjalan sesuai harapan atau tidak [12]. Berdasarkan pengujian black box yang telah dilakukan pada seluruh fitur yang terdapat dalam sistem, fitur-fitur tersebut diuji dengan berbagai data masukan. Sehingga didapat kesimpulan bahwa fitur-fitur yang ada pada sistem informasi pengarsipan barang pada PT. Tunas Jaya Sanur telah berjalan dengan baik.

\subsection{Kuesioner}

Penulis menanyakan kepada staf admin karyawan dan staf admin gudang selaku operator mengenai sistem yang telah dibuat, apakah sistem sesuai atau tidak dengan kebutuhan. Jika belum sesuai, maka akan kembali ke perancangan sistem hingga sesuai dengan keinginan dan kebutuhan pengguna. Untuk mengetahui hal tersebut, maka dilakukan evaluasi melalui kuesioner. Parameter pengujian yang digunakan pada metode ini adalah:

a. Apakah sistem yang dibuat sudah sesuai dengan kebutuhan pada PT. Tunas Jaya Sanur?

b. Apakah sistem yang dibuat dapat mempermudah pegawai dalam mengelola informasi barang?

c. Apakah sistem yang digunakan mudah digunakan?

d. Apakah sistem menghasilkan informasi yang detail?

e. Dalam hal tata letak (design), apakah sistem mudah untuk dibaca dan dipahami?

f. Apakah sistem sudah bekerja sesuai dengan kegunaan dan fungsinya?

Responden akan diberikan pilihan jawaban dari pertanyaan-pertanyaan tersebut, sebagai berikut:

a. Ya

b. Tidak

Hasil rekapitulasi jawaban responden dihitung dari jawaban berdasarkan pengisian kuesioner dari masingmasing pertanyaan. Berikut merupakan grafik persentase jawaban rata-rata hasil pengujian dari 2 responden:

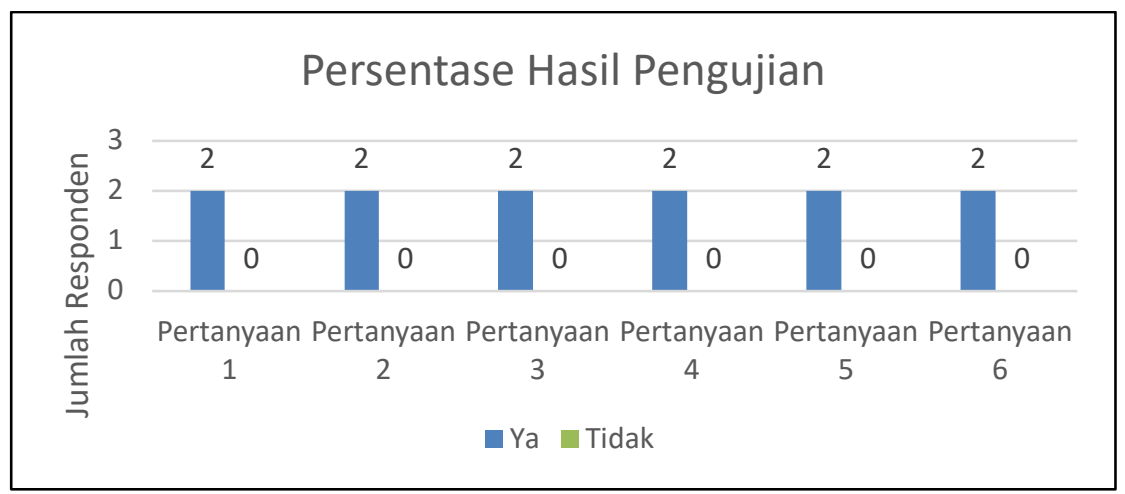

Gambar 13. Persentase hasil pengujian

Gambar 13 merupakan hasil dari persentase pengujian dari kuesioner yang diberikan, didapatkan nilai pada seluruh pertanyaan responden memilih pilihan ya atau setuju. Sehingga dapat disimpulkan dari hasil pengujian bahwa hasil dari kepuasan terhadap sistem yang sudah dikembangkan setuju untuk sistem informasi pengarsipan barang yang dirancang dan dibuat.

\section{KESIMPULAN DAN SARAN}

\subsection{Kesimpulan}

Berdasarkan hasil Praktik Kerja Lapangan di PT. Tunas Jaya Sanur didapatkan kesimpulan yaitu, sistem informasi inventarisasi barang yang dibuat dapat digunakan untuk melakukan pendataan, pengelolaan, inventarisasi, serta mencetak daftar barang masuk dan barang keluar oleh PT. Tunas Jaya Sanur.

Fitur-fitur yang terdapat pada sistem informasi inventarisasi barang ini, seperti data permintaan barang, restock barang, dan profil masing-masing memiliki fungsinya sendiri. Fitur-fitur ini dapat mempermudah pengelolaan barang yang dulunya dilakukan melalui aplikasi spreadsheet. 


\subsection{Saran}

Berdasarkan sistem informasi pengarsipan barang yang telah dibuat, penulis menyarankan beberapa hal agar sistem ini dapat lebih baik lagi ke depannya, yaitu melakukan perbaikan pada tampilan serta menambahkan fiturfitur baru untuk dapat lebih menunjang kinerja dari sistem dan memudahkan operator dalam mengelola barang. Kemudian menambah fitur keamanan agar sistem dapat lebih aman semisal dengan menggunakan framework seperti codeigniter sehingga setiap halamannya tidak bisa diakses langsung melalui link.

\section{DAFTAR PUSTAKa}

[1] Brian K. Williams dan Stacey C. Sawyer, Using Information Technology (Terjemahan Indonesia), Yogyakarta: Andi Offset, 2007.

[2] Arni Muarifah Amri dan Kurnia Cahya Lestari, Sistem Informasi Akuntansi (Beserta Contoh Penerapan Aplikasi SIA Sederhana dalam UMKM), Yogyakarta: Penerbit Deepublish, 2020.

[3] Rohmat Taufiq, Sistem Informasi Manajemen, Yogyakarta: Graha Ilmu, 2013.

[4] Jogiyanto Hartono, Analisis dan Desain Sistem Informasi, Yogyakarta: Andi Offset, 2005.

[5] Tata Sutabri, Analisis Sistem Informasi, Yogyakarta: Penerbit Andi, 2012.

[6] Prijambodo, Out of The Box: Koperasi Tantangan Perubahan Kini dan Masa Depan, Yogyakarta: Phoenix Publisher, 2018.

[7] Haviluddin, "Memahami Penggunaan UML (Unified Modelling Language)," Jurnal Informatika Mulawarman, vol. 6, no. 1, hal. 1 - 15, Februari 2011.

[8] Peranginangin, Teknik Cepat Menguasai PHP MySQL dalam Waktu yang Sangat Singkat, Jakarta: Kuncikom, 2016.

[9] Husein Alatas, Responsive Web Design dengan PHP dan Bootstrap, Yogyakarta: Lokomedia, 2013.

[10] Priyanto Hidayatullah, Pemrograman Web, Bandung: Informatika Bandung, 2015.

[11] Christanus Tristanto, "Penggunaan Metode Waterfall untuk Pengembangan Sistem Monitoring dan Evaluasi Pembangunan Pedesaan,” Jurnal Teknologi Informasi ESIT, vol. XII, no. 1, hal. 8 - 22, April 2018.

[12] Sumiati, Sri Endang Anjarwani, dan Moh. Ali Albar, "Rancang Bangun Sistem Informasi Pengelolaan Barang dan Kearsipan pada Sekretariat Daerah Provinsi NTB Berbasis Web," J-COSINE, vol. 2, no. 1, hal. 7 - 16, Juni 2018. 